\title{
Religious Turns: \\ Immigration, Islam, and Christianity in Twenty-First Century German Cultural Politics
}

Claudia Breger

Indiana University

The paper analyzes recent German headscarf legislation in the context of early twenty-first-century religious turns, that is, on the one hand constructions of "Islam/ism" as the newly dominant figure of cultural difference on the political stage, and on the other hand the renewed prominence of Christianity in public discourse. Against the background of current academic work on and in political theology, I analyze the "post-secular" concepts of collective identity developed under the sign of the headscarf by associating them with two different theoretical models. Berlin's headscarf legislation can be compared to the French "Law on Laicity," which has been criticized as a vehicle of hidden political theologies in Carl Schmitt's sense: the Republic performs its sovereignty through the ways it manages religious exceptions. The openly asymmetrical headscarf bans passed in a number of other German states, however, do not just make "exceptions" for Christianity; rather, they privilege "Christian tradition" as the foundation of the "secular" German state. Critically relating this rhetoric to the ways in which Jean-Luc Nancy and Slavoj Zizek conceptualize the (presumably inescapable) destabilization of secular democracy through the forces of heteronomy and tradition, the paper pleas for replacing such uses of political theology in both politics and theory.

\section{Introduction'}

In December 2005, the New York Times Magazine published an article entitled "The New Berlin Wall." Authored by Peter Schneider, a well-known German writer generally identified with the left-wing legacy of 1968, the piece begins by discussing a recent series of so-called honor killings (Ehrenmorde). After the murder of Hatun Sürücü by her brother in February of that year in Berlin, these crimes had had a significant presence in the German media throughout 2005. As suggested by the article title, Schneider develops their discussion into a larger narrative about "a new wall rising in the city of Berlin" (and, by extension, Germany) - a "parallel society" which presented "the German majority" with the results of failed immigrant integration (68-69). "Until recently," Schneider suggests, "most Berliners held to the illusion that living together with some 300,000 Muslim immigrants and children of immigrants was basically working," but that began to change in the aftermath of September II (68). For his American readers, Schneider emphasizes that the latter event made many Germans for "the first time [...] wonder who their neighbors really were," as "hundreds of rockets were shooting skyward in celebration of the attack" in Berlin-Neukölln and Kreuzberg while "the German majority" declared "“unconditional solidarity” with Americans" (68). "[P]roud of its isolation” (69), the 
(terrorist-affiliated) "parallel society" in the heart of Berlin had been growing, Schneider claims, on a German soil fertilized by "the guilt-ridden tolerance of liberal multiculturalists" (7I). As its problematic kernel, however, he identifies the radical potential of "Islam" itself, a religion which has failed to modernize itself through "something" equivalent to the European "Enlightenment" (7I).

I begin my own piece with this summary of Schneider's essay because, in an exemplary way, it assembles a configuration of topoi and tropes which characterize shifting immigration discourses in twenty-first century Germany. Framed by the ongoing debate about Turkey's candidacy for EU membership, a series of controversies and scandals has kept questions of immigration —or more specifically: the challenges of “integrating” Germany's Turkish and Arab immigrant communities - almost constantly in the media over the course of the last years. The most persistent and perhaps most symbolically significant of these controversies is that surrounding headscarves in German public schools, which will be the focus of my attention in this piece. However, this particular debate can be fully understood only by looking also at how it is framed by multiple related discourses, ranging from Schneider's topic of honor killings and intermittent debates on the construction of mosques in German cities to an anxious focus on German converts to Islam in the fall of 2007 (on the latter, see Ozyurek). Together, the various controversies have effected what an article in the liberal weekly Die Zeit describes as an increasingly aggressive "Kulturkampfklima."2 For many, these developments have come as a surprise. Just a few years ago, a majority of critics believed that Germany was finally on its way towards accepting its status as a country of immigration. Namely, the 2000 citizenship legislation reform had relativized the national legacy of ius sanguinis, that is, of defining citizenship in terms of heritage and implicitly race, thereby paving the way for turning Germany's third-generation “foreigners” into citizens.

Within the last few years, however, the tables seem to have turned--arguably in fact in response to September II, as suggested by Schneider, and the following wars. This contextualization underlines that the new Kulturkampf is to be seen in a transnational context. Not only in Germany, but also in the U.S., France, the Netherlands and Britain, political conflict has been increasingly coded in cultural terms (see Brown 298, with reference to Mahmood Mamdani). With national variations based on different concepts of immigration and citizenship, discourses of "failed integration," the critique of "multiculturalism" and the spread of revitalized 
Orientalist patterns have acquired a relative hegemony all over Western Europe and the U.S., where Schneider's article found its readership. From a German studies angle, however, these discourses nonetheless also pose questions about how the current transnational climate has facilitated the rearticulation, and relegitimization, of a national legacy of exclusion, which is characterized by culturalized, implicitly racialized concepts of national identity.

Sociological research has adopted the notion of "Islamophobia" for the new, outspoken hostilities towards Germany's largest immigrant communities, and suggested that such "phobia” has become acceptable far into liberal and intellectual circles. ${ }^{3}$ This identification of the problem is indicative of the discursive shifts marked in the title of my paper: unlike their twentiethcentury counterparts, the new discourses on immigration are focused on religion (as, not least, cultural identity) rather than ethnicity or nationality (see also Cesari and McLoughlin 3). At the intersection of new concepts of transnational belonging and post-September II terror discourses, the figure of difference dominating the early twenty-first century German public stage is no longer "the Turk" but the "observant" or/as "radicalized Muslim."

In the context of this issue on political theologies, my essay pursues the imbrications of politics and religion both highlighted and produced by these shifts. I begin by showing how "Islam/ism" is constructed as a form of political theology in contemporary debates. More centrally, I then discuss the ways in which these discourses intersect with, and are developed through the return also of Christianity on the political stage, that is, the implicit and explicit forms of Christian political theology inscribed in them. The German headscarf debate provides a particularly dense articulation of what I thus describe as Religious Turns in contemporary Germany. My paper conceptualizes these headscarf affairs against the backdrop of recent theoretical discussions on politics and theology. Specifically, I characterize the ("post-secular") concepts of collective identity developed under the sign of the headscarf by reading them with and against Carl Schmitt's, Jean-Luc Nancy's and Slavoj Zizek's concepts of political theology. Before delving into the specifics of these affairs, however, the first part of my paper frames the headscarf controversy in some more detail within the broader discourses on Islam, Christianity and immigration that have surrounded its emergence over the course of the last few years. 


\section{Headscarfs in Context: Constructions of Islam/ism in post-secular}

\section{Germany}

Schneider's article suggests that the new focus on religion does not erase older ethnic, national and geographic significations. Rather, all of these feed into the construction of "Islam/Islamism" as a cultural category. Schneider's reference to Islam's presumed need for Enlightenment points to the central asymmetrical opposition which structures the discourse in question: in a move supported by well-known Orientalist tropes of "Eastern backwardness," "Muslim fundamentalism" is opposed to ("modern") "Western secularism." At the same time, the way in which Schneider maps the trope of "parallel cultures" onto national historical and current transnational terrain indicates that these new discourses do not merely reiterate familiar patterns. Thus, the title metaphor of the new wall seems to indicate acknowledgment of the fact that the Islamic "Easterners" are German, too. Nonetheless, the "revelation" of September $\mathrm{II}$ in his narrative is staged in essentialist terms as one about who these neighbors "really were" (my emphasis).

On the level of explicit argument, Schneider suggests that Islam can be reformed, and does thus not constitute a necessarily "alien essence." He himself, however, highlights other prominent voices in the contemporary debate which foreclose that possibility. Reflecting Schneider's praise, the New York Times article features a whole-page photograph of the "Muslim dissident [...]" (68) Necla Kelek, whose 2005 bestseller Die fremde Braut (The Foreign Bride) made her into one of the token voices on Islam in German public discourse. ${ }^{4}$ Die fremde Braut, as well as Kelek's follow-up piece on Turkish masculinities, Die verlorenen Söhne (The Prodigal Sons, 2006) develop a critique of Islam which is reminiscent of the double bind created by the co-emergence of Enlightenment assimilation politics and racist thought in eighteenth-century German-language discourses. As in Schneider's narrative, Islam-to which Kelek thus regularly refers in the singular form-is charged with resisting modernity, i.e. not yet having gone through a process of enlightenment (Die fremde Braut 153; Die verlorenen Söhne 201). At the same time, however, the demand for modernization is imaginatively counteracted by a second rhetorical move which identifies Islam with "barbarism" qua religious essence, as exemplified by Islamic practices of ritual slaughter. ${ }^{5}$

Unlike in the nineteenth and early twentieth centuries, these newly essentialized religious culturalisms are not explicitly bound up with racial distinctions. However, they are 
certainly haunted by the legacies of modern racism. With Schneider's article, it is particularly the photos - and photo-captions - which carry respective subterraneous messages. Thus, the murder victim Hatun Sürücü is represented through a sexualized image which emphasizes her comparatively dark coloring; the caption raises specters of racial hybridity in suggesting that the fact she "embraced German culture" may have "caused her death" (69) at the hands of her brothers, who are shown next to her as "shadowy" figures in a black-and-white courtroom scenario drawing. Explicitly, racism figures only as a specter from a "dark" past in Schneider's article-a specter that is identified as the cause of "false guilt" and "false tolerance" in contemporary immigration discourses (on these tropes see Yildiz). According to Schneider, the German majority has failed to counteract the rise of the Muslim "parallel society" because of its quasi-religious attachment to rigid history lessons: "For a German of my generation, one of the most holy legacies of the past was the law of tolerance" (68).

From that perspective, ongoing processes of racialization are disregarded in Schneider's analysis of growing religious observance and radicalism in German Muslim communities; the more encompassing factor of social marginalization is mentioned but downplayed ("this explanation is incomplete, to say the least," 70). Instead, Schneider blames the emergence of the "parallel society" on "the active refusal of many in the Muslim community to integrate" (7I). More aggressively, other participants in the contemporary debate develop this argumentative cluster as the recurrent charge of discursive interdictions. Presumably, politically correct warnings against "Islamophobia" disallow the necessary discussion of connections between Islam and violence (e.g. Feddersen). Schneider is careful to avoid all-too-grand generalizations of this kind. While other prominent authors have explicitly argued against differentiating between "Islam" and "Islamism" (see for example Broder), he does so in principle. However, his more subtle rhetoric facilitates comparable conclusions, for example when his text ends by emphasizing the "fact" that "disregard for women's rights [...] is an integral component of almost all Islamic societies, including those in the West" (7I).

In this regard as well, Schneider's article provides an exemplary condensation of current motifs: the notion of "unenlightened" gender politics takes center-stage in Islam/ism's contemporary cultural construction. The significance of the German headscarf debate results not least from the particular ways in which these gendered constructions inflect contemporary 
German —and also broader European-discourses on immigration. Whereas in the U.S., postSeptember I I discourses have arguably been specifically marked by a focus on "queer" terrorist masculinities (as analyzed by Puar), the German early twenty-first-century debate is more dominantly characterized by a forceful return of the trope of the oppressed Muslim woman. This trope had already been highly influential a few decades ago in early German discourses of Turkish immigration, but in the course of the nineties, it seemed to have been replaced by more complex imaginations of gender and cultural difference (Adelson 129).

The renewed focus on this figure of religio-cultural difference today can be interpreted in the tradition of Orientalism and colonial discourses. With the championing of voices like Necla Kelek's, the proverbial colonialist fantasy of "white men saving brown women from brown men" (see Spivak) is rewritten as an ostensibly "feminist" fantasy of "heroically whitened/europeanized brown women saving unenlightened brown women from barbaric brown men." At the same time, the prominence of the headscarf trope also invites questions about historical memory and the tense configuration of "denial and obsession" with matters of race in post-fascist Germany (El Tayeb 29). Whereas commentators endlessly reinscribe the cultural differences which they claim they are not allowed to mark in contemporary discourse, gender — and, to some degree, sexuality (see, e.g., Feddersen) — trumps race in the competition for media attention when it comes to critiquing discrimination and hate crimes. While headscarves, "honor killings" and sometimes also "Islamic" homophobia have made the headlines all over Germany's media landscape in the last few years, there has been comparatively very little discussion of (be it "Islamic" or other) anti-Semitism, despite indications of growing numbers of openly anti-Semitically motivated assaults, which may show a confluence of respective affects and ideologems in German Neo-Nazi, left-wing anti-imperialist and marginalized immigrant communities. ${ }^{6}$ As my discussion of the headscarf debate will substantiate, the media focus on the oppressed, headscarf-wearing Muslim woman thus indirectly points also to German society's continued unease with Judaism, which can no longer be openly marked as "other," but is still often not recognized as an integral part of German tradition as well as contemporary society. ${ }^{7}$

Equally crucial, and more visible on the surface, is the role of the third monotheistic religion-Christianity-for the construction of Islamism in early twenty-first century German discourse. The plural form of my title wording, Religious Turns, underlines that not only Islam 
has won a new presence and significance in the German public sphere, but also Christianity. These turns do not function in the same ways, and not internally homogeneously, either, finding their individual forms in different socio-symbolic contexts. Thus, there may be some truth to the common perception that German churches remain relatively empty, whereas German mosques, if neighbors do not prevent their construction in the first place, are attended by growing numbers of praying men and women (see Klausen I38-140). This asymmetry can be evaluated in terms of social marginalization; ${ }^{8}$ however, it would be too easy to conclude that the majority of Germans have remained at a distance from religion per se. Even while church attendance remains low, sociological data show an increase in religious commitment also on the Christian side (Klausen 138). Indicators like the emergence of religious television and radio programs, the media hype around the current pope as well as the increasingly prominent use of religious topoi in political argumentation and cultural production suggest that the significance of Christianity in media and society has shifted over the last few years. Embracing this trend, conservative critic Adolf Muschg suggested that Christianity was woken up from its "torpidity" (Erstarrung) by Islam (as cited by Lau).

Muschg's comment points to the fact that the return of Christianity onto the public stage does not yet undo the dichotomy of "Western secularism" versus "unenlightened Islamism." Rather, this return foregrounds a differential construction of religiosity which has been a familiar element particularly of U.S.-American discourses, whose proponents have sometimes positioned their nation in opposition to (all-too) "secular" Europe in the war on terror-context (see de Vries 5). As described by Wendy Brown, this construction allows those proponents to "sharply differentiate [...]" President Bush's prayers "from the-dangerous - devotion to Allah of a Muslim fundamentalist" through the claim that in Western ("enlightened," or, in Brown's words, "liberal”) societies, religion functions "as a choice and as a source of comfort, nourishment, moral guidance, and moral credibility" rather than "as domination, tyranny, or source of irrationality and violence" (30I). In this differential construction, the relations between politics and religion are arranged in a way which locates political theology, in the sense of an anti-democratic, anti-liberal meshing of the two, on the side of the other, while claiming a "proper" management of the relation for oneself." 
In the German context, this differential construction has gained prominence in the context of the outlined media scandals (see, e.g., Schmitthals). In a paradigmatic way, it is developed in Kelek's Die verlorenen Söhne (The Prodigal Sons), which unfolds its Christian title metaphor in a critique of previous migration scholarship, where it has functioned as a metaphor for the becoming-problematic of traditional identities in modern societies (17). In Kelek's version, the Turkish sons she interviewed for her study have lost themselves precisely because they followed the laws of their fathers (209), rather than in fact completing the alternative, “modernizing" path described in the Christian bible. Beyond the title metaphor, Christianity figures as guidance on this path in Kelek's narrative. Singling out "Max Weber and Jesus” (I89) as two spiritual or intellectual (geistig) mentors on what she describes as her own progress towards individuality, she draws on Weber's work on the sociology of religions to characterize Islam as a feudalistic "Herrenreligion" (the Orientalist clichés in Weber's account are reproduced without any critical contextualization). While for "Mohamed, religion and politics were one" (163), Jesus stands in for an anti-authoritarian religion based not on law but love (192-193) in Kelek's account. Within this configuration-in which Islam is characterized through some of the tropes often also associated with Judaism in Christian discourse - the Christian faith is synecdochically identified with its modern, enlightened elaboration (I82; see also Die fremde Braut, 243).

It is not difficult to deconstruct the differential construction Kelek develops. While distinguishing Christianity as the religion of individuality freed from tradition, she keeps using the first person plural when, for example, suggesting that the entire spirit of "our religious [Christian] culture [read: tradition?, CB] opposes violent sacrifice and presumably holy violence” (Die verlorenen Söhne 162). Providing classical Gemeinschaft-Gesellschaft distinctions with an interesting twist, she celebrates the historically evolved European "Gemeinschaft” (203) while warning against "collectivist" identities like "Turkishness" (203) and "treacherous" formulae like "us Muslims" (208). The "treacherous" crossover of the first person plural from the Islamic to the Christian side in Kelek's comparative narrative points to the political theologies which are implicitly inscribed in her differential construction. Already Die fremde Braut concluded with a reference to her belief in "the gospel of freedom" (266). Her own use of Christianity signals that beyond the "other" world of Islam, (majority) German early twenty- 
first discourses are structured by a "contested nonseparation" of religion and politics (de Vries 29).

In his recent collection on Political Theologies, Hent de Vries conceptualizes the contemporary state of affairs in terms of the "post-secular." With reference to Hans Joas, he emphasizes that the notion designates not necessarily a sudden increase in religiosity, and not a shift in the nature of the secular state, either, but a shift in the state's "'secularist selfunderstanding"' as well as more generally the "'mindset of those who, previously, felt justified in considering religions to be moribund”' (de Vries 2-3). In analogy to earlier discussions on concepts like postmodernism or postcolonialism, the terminus "post-secular" thus carries reservations vis-à-vis simple historical periodization. Rather than the end of secular modernity, the new interest in religion then highlights the fissures in, or simply the complexities of, modern identities.

While sharing this analytical commitment to the fissures of modernity, I nonetheless hesitate to completely follow de Vries when he supplements the historical with a structural perspective, describing the post-secular "as a topical indicator for-well, a problem" (de Vries 2). Although careful to word his interventions in a tentative mode of questioning rather than that of a definite constative, de Vries joins Claude Lefort in emphasizing the "permanence of the theologico-political," that is, the transhistorical dimension and "irremovable" nature of the imbrication between the political and the religious (de Vries 28-29, quoting Lefort). With this curious insistence, de Vries's introduction to one of the major anthologies in the newly emerging field of political theology studies marks a broader trend. Contemporary theory's new interest in political theology is not merely analytical; rather, it stages a (methodological) “conversation with theology” (Williams 3). In embracing "transcendence” (see de Vries 28), (some) twenty-first century theory is performing its own religious turn. ${ }^{10}$

On the one hand, this turn is articulated as a new interest in-notably ethical-foundations in response to the presumed impasses of "relativist" late twentieth century "theory," a.k.a. postmodernism (see, for example, Eagleton in his After Theory). On the other hand, this recent work also continues to build on a number of postmodernist themes, notably the fascination with figures of complete otherness and a beyond (the law, etc.). Attesting to the fissures of postmodernist theoretical discourse, theology seems to offer itself 
as a "salvatory" mode of theorizing in the "post-theoretical" age. From my own perspective, however, this theological turn is neither necessary nor particularly promising. While I do not believe that the question of ethics needs to be approached from a transcendental angle (see also Laclau 147), I mistrust the potential authoritarian implications of invoking an(y) authoritative "beyond." Therefore, I approach the question of political theologies from a historicizing angle. Rather than postulating any permanence in the fraught relations between the political and the religious, my title notion "religious turns" thus emphasizes that "[t]he ways in which the concept of 'religion' operates" in culture "as motive and as effect" are "not eternally fixed" (Asad 526). Although the contemporary moment under investigation is not "postsecular" in any linear sense of a historical moment "beyond" secularism or modernity, I claim that it is different from previous modern moments in that religious tropes and topoi are newly foregrounded. While these tropes and topoi did actively help to constitute modern identities throughout the last centuries, despite and even through their common association with the pre-modern, they are currently rhetorically underlined and reconfigured, with the effect of increasing their relative force in a shifting field of socio-symbolic articulations of identity and difference. A closer look at the German headscarf affair will allow me to unravel these claims.

\section{The German Headscarf Affair: An Outline}

In 1998, Fereshta Ludin, an Afghan-born German citizen, was denied placement in BadenWürttemberg's public school system after successfully completing her teacher training period (Referendariat). The notice from the local education authority read that her declared intention to wear a headscarf constituted a lack of "Eignung" (qualification/eligibility) for the status of "Beamte/r," which is still usually conferred upon permanent teachers in German public schools. " Ludin took the case to the courts, making her argument based on her right to religious freedom as guaranteed by Article 4, I-2 of the German constitution (see BVerfG Abs. 4 and 16). In a series of appeals and legal decisions, the administrative courts of the city of Stuttgart (March 24, 2000), the state of Baden-Württemberg (June 26, 200I) and the Federal Republic (July 4, 2002) found against Ludin, variously arguing that her positive right to religious freedom was limited by the pupils' "negative" right to religious freedom and the state's duty to neutrality (see BVerfG Abs. 6-I5 for an overview, also BVerwG 2 C 2I.0I). 
On June 3, 2003, however, Germany's federal constitutional court, the Bundesverfassungsgericht, overruled all of these decisions. The majority opinion stated that Ludin's constitutional rights of equal access to public office in conjunction with that of religious freedom had in fact been violated (BVerfG Abs. 30). Importantly for the following events, however, the court qualified this decision with the consideration that "at the moment," there was no "sufficiently defined legal basis" for restricting Ludin's rights in the given situation. ${ }^{12}$ Declaring that "in principle," the legislator had "ample freedom of scope" in specifying eligibility criteria for public office," ${ }^{\prime 3}$ the court fairly explicitly called for respective legislation in the individual German states. Specifically, the decision suggested that "social change that comes with increasing religious plurality can provide an occasion for legal redefinitions of the degree to which religious references are acceptable in [public] schools." 14

This decision by Germany's Supreme Court resulted in a number of legal initiatives in different German states. These initiatives, many of which have become effective law by now, followed two different models. In Berlin, a controversial piece of legislation introduced a laicist model of restricting religious references, which can be compared to the French headscarf ban passed in 2004. Most legal initiatives in individual German states, however, opted for the second model. "[N]otoriously" violating, in the words of one critic, the principle of state neutrality "through the selective exclusion of Islamic symbols" (Joppke 330, 328), these recent laws explicitly follow the logic of differential religiosity I outlined above. Asymmetrically, they privilege references to "Christian," "Christian-occidental" or "Christian and humanist" traditions over the use of Islamic signs in public schools, while the status of Jewish symbols often remains ambiguous. Thereby, these laws map the German public sphere as a terrain governed not by universalist Enlightenment values, but by a culturally circumscribed, specifically Christian heritage (Amir-Moazami 128, 143). While the categories of neutrality and secularism have nonetheless been evoked in these contexts, they have been defined through values that evolved out of, and are thus to be seen in the direct tradition of (enlightened) Christianity (see ibid, I08-I I0), in contrast to the Islamic "political theology" presumably signified by the headscarf.

The legal background of these argumentations - which, as many critics insist, does not equal their legitimation-is provided by the specific way in which the relationship between 
church and state has been conceptualized in Germany since the Weimar Republic. Different from the French model of strict separation between church and state, but also from the State Church model operative in some other European countries, the formal "separation" between church and state has been constitutionally articulated as a relationship of "cooperation" between the two institutions (Fetzer and Soper 105, see Klausen 144). Various churches-as well as several Jewish, but so far no Islamic organizations-have been granted the status of public corporations (Körperschaften des öffentlichen Rechts), which comes with substantial privileges including government-collected church taxes, religious instruction in public schools, church representatives on public radio broadcasting and television boards and state funding for theological colleges. ${ }^{15}$ In the controversies surrounding the headscarf, this legal tradition has been sharply criticized as a condition of incomplete secularity (Kleff 86).

With respect to the ways in which this tradition is foregrounded and reconfigured in the ongoing debates, I conceptualize the asymmetrical headscarf bans in different German states as a (majority-) German articulation of post-secularity in the twenty-first century. I begin with a comparative glance at the laicist model, which itself has been criticized as a vehicle of hidden political theologies. For the French context, Talad Assad conceptualizes its workings through Carl Schmitt's model of sovereignty as the managing of-here religious-exceptions. While I find this analysis convincing, I argue that this model alone is not sufficient for conceptualizing the explicitly non-laicist German headscarf legislations, which associate secularism with Christianity through a model of foundational continuity rather than exception. In a more detailed discussion of the juridical rhetoric employed here, I critically connect the German discourses at play to other recent conceptualizations of political theology, in particular those of Jean-Luc Nancy and Slavoj Zizek. In a different context, I have criticized Zizek's theoretical model for what I take to be its anti-democratic implications (Breger). Precisely with this reading in mind, however, I suggest here that we can use some of its facets to theorize the ways in which contemporary majority German discourses operate. In highlighting this connection, I hope to underscore the need for moving beyond such uses of political theology.

\section{Paris-Berlin: The Fissures of Laicism}

Accompanied by loud protests from churches and Christian parties, the Social DemocratSocialist coalition (SPD/PDS) governing the city of Berlin in January of 2005 passed a law 
banning all "visible religious or ideological [weltanschaulichen] symbols" and clothes (Berlin). Adopted in the name of anti-discrimination policy as well as the state's duty to neutrality, this law applies not only to teachers, but to state employees in the entire public service sector. The most wide-reaching ban passed in Germany, ${ }^{16}$ this piece of Berlin legislation comes closest to the controversial, internationally discussed 2004 French "Law on Laicity.” Unlike its Berlin counterpart, the French law includes students as well, and its wording differs slightly in that it bans not straightforwardly "visible" signs, but "signs or dress through which students ostensibly [ostensiblement] manifest a religious belonging" (quoted from Joppke 3/7-3/8). In a number of ways, the critical debate on the French legislation can nonetheless be usefully applied to the Berlin version as well.

As critics have emphasized, the French law belongs in the context of France's assimilation-oriented immigration politics. At the expense of the protection of individual rights, it affirmed abstract universalism and "unity over and against a diversifying immigrant society" (Joppke 325; see Amir-Moazami 36). In terms of relations between religion and politics, the "Law on Laicity" underlines the "combative" model of the latter prevalent in French postrevolutionary history, which bases Republican identity on the separation of state and church (Joppke 318, with reference to Fetzer and Soper). In recent discussions on the return of political theology in modernity, this model has been described as performing its own quasireligious move: not fully "laicized" in every respect, the Republic itself is provided with a "sacred aura" through its installment in the place of traditionally religious authority (see ibid., 3|8-3|9).

This return of the sacred in the process of political abstraction, however, is only part of the story. Importantly, the 2004 law does not in fact neutrally target all religious symbols equally. Generally referred to as the "Islamic veil affair," the legislation process developed out of a discourse of threat with which political Islam presumably presented the secular character of the Republic (Asad 497). Not surprisingly perhaps, the wording of the resulting law ("ostensible signs") affects headscarves differently than small crosses. In the Berlin case, the word choice "visible" may seem less ambiguous in this regard. Here as well, however, the process of legislation was provoked by the quoted Supreme Court decision on a headscarf case, and the asymmetry inscribed in that context returns in the political rhetoric evaluating the legal 
wordings. Thus, parliament members as well as media commentators have suggested that the Berlin law exempts symbols "which are worn as pieces of jewelry, like small crosses." I7 In this sense, the legislation asymmetrically demands "state service without headscarf or Kippa" (Schulz). In other words, even the ostensibly inclusive wording of the Berlin law does not escape the larger, discriminative social configuration in which visibility is a matter of norms rather than simply size: the headscarf has been regularly described as a highly or “conspicuously" visible sign in the ongoing debates (see Weber 46).

In Talal Asad's discussion of the French case, the asymmetrical interference of the (Islamic) specter of "uncontrolled religion as dangerous passion, dissident identity" and "foreign power" attests to the fissures of modern secularism itself (498). As he highlights, the separation of state and church was never complete even in fiercely laicist France. While unlike their Polish contemporaries, French people may generally be "strongly opposed to any mention of religion in the EU constitution," many of them "have no difficulty in speaking of their Judaeo-Christian legacy"” (495). Asad conceptualizes these tensions within the French concept and practices of laicity with Carl Schmitt's notion of sovereignty, defined as the power to decide in and upon the state of exception. Thus, the secular French state performs its sovereignty through the asymmetrical principle that religion is never allowed to "intervene in matters of state," while the state has the power of handling exceptions-including, for example, the possibility of granting privileges to churches based on regional tradition (505). As an exercise in this sovereign power, the headscarf ban thus operates within the orbit of a "Republican political theology” (507), which does something more specific than merely re-instating a modern instance of the sacred in the political world. Namely, this Republican political theology is directed against the "internal enemy" of Islam which has become an integral component of French secular identity in the histories of Orientalism and colonialism (5I0).

To my knowledge, a similar argument has not yet been made with respect to the Berlin “neutrality" law. While the recurring political rhetoric regarding jewelry exceptions may certainly invite it, this absence of an analogous debate simultaneously makes sense in a larger socio-discursive context quite different from the French situation. In Berlin, the left-wing coalition's attempt at legally prescribing (relative) laicist neutrality was deemed radical enough to provoke harsh reactions from conservative parties and churches, which interpreted the law 
as an illicit restriction of positive religious freedom (see, e.g., Henkel). Most of the laws initiated in other German states privilege Christianity in much more explicit ways.

\section{From Baden-Württemberg To Lower Saxony: The "Substantial Ties" of Christian Tradition}

The first German state to respond to the Supreme Court decision was Baden-Württemberg, where Ludin's case had originated. Because of its model character for subsequent legislation in other German states as well as the significance of its rhetorical constitution, I translate the relevant passage added to the state's school law in full:

$\S 38$ (2) Teachers in public schools as defined by $\S 2$ Abs. I may not make any political, religious, ideological or similar outward demonstrations suited to endanger or disturb the neutrality of the state in relation to pupils and parents or the political, religious or ideological school peace. Not permissible are, in particular, outward appearances/behavior which can create the impression with pupils or parents that a teacher acts against human dignity, equal rights as defined by Article 3 of the German basic law, basic rights to freedom or the liberaldemocratic constitution. The fulfillment of the educational mandate as defined by Article 12 Abs. I, Article 15 Abs. I and Article 16, Abs. I of the constitution of Baden-Württemberg and the respective representation of Christian and occidental educational and cultural values or traditions do not violate the rule established in sentence I. ${ }^{18}$

The significant argumentative move in this text is the way in which "neutrality" is developed, via the intermediary notions of "school peace" and "the liberal-democratic constitution," as compatible with the "representation of Christian and occidental educational and cultural values or traditions," based on the "educational mandate" specified in the state constitution. The quoted article 12, paragraph I demands raising the country's youth “in reverence of God, in the spirit of Christian neighbor love."19 On the basis of this specification, it may in fact seem evident that headscarves disturb the "religious peace" in school in a fundamentally different way than crosses of various kinds. While the law locates the specter of authoritarian political theology in the (implied) signs of Muslim identity, it quite explicitly grounds itself in Christian religion. 
So does subsequent legislation in a number of other German states, using variations on the same topoi. Hesse's addition to the country's Beamten- and school laws states that decisions as to which pieces of clothing or symbols are "objectively" (sic) suited to "affect confidence in the neutrality" of a teacher's work or "disturb the political, religious, or ideological peace" in school shall be made with "adequate" regard for the "Christian- and humanistically shaped traditions of the country." ${ }^{20}$ In Lower Saxony, "the outward appearance of teachers may not motivate any doubts about their qualification to fulfill the school's educational mandate in a convincing way"-a mandate defined as that of developing the students' personalities "on the basis of Christianity, European humanism and the ideas of liberal, democratic and social movements for freedom."2l The Bavarian law specifically bans symbols which "can also be understood as expressing a position which is not compatible with" the "educational mandates of the constitution including Christian-occidental educational and cultural values." 22 While these new laws rearticulate references to Christianity already written into the pre-existing legal bodies, Saarland legislators added a respective clause to the state's school law: "In befitting consideration of the feelings of students with different beliefs, schools educate students on the basis of Christian educational and cultural values."23

While openly designed to ban headscarves, it is less clear how these different laws affect Kippas (see, e.g., Rødstøl). Various political and media commentaries assert that banning them as well is not the intended effect of the legislation in question; however, none of the laws explicitly exempts Judaism together with Christianity. At best, the repeatedly used conjunction of "Christian" and "occidental" ambiguously includes Jewish religious symbols, if we assume that the official consensus of post-fascist German society defines “occidental” as "Judeo-Christian" traditions. Independent of any direct practical consequences, the conscious omission of the third monotheistic religion in the asymmetrical headscarf bans certainly highlights that German majorities are still not ready to fully acknowledge the country's Jewish heritage, instead clinging to a continued fiction of Christian cultural and religious homogeneity.

The privilege granted to Christianity in these various legislations has not remained unchallenged, but so far the courts have mostly accepted the new laws. Ludin's case against the Baden-Württemberg legislation was turned down by the Federal Administrative Court (June 2004, see Weber) and the Bavaria and Hesse constitutional courts affirmed the respective state laws in January and December 2007 (with a very slim minority in the second case, see Rath). 
The legal hermeneutic at work in these decisions functions along the lines of the differential construction discussed above. Thus, the Bundesverwaltungsgericht declares that the BadenWürttemberg law does not privilege Christianity in that the notion designates "a world of values detached from articles of faith, following from the tradition of Christian-occidental culture, which discernibly laid the foundations for the Basic Law as well." ${ }^{24}$

The legal precedents quoted in this context are two earlier federal Supreme Court decisions. In December 1975, the Bundesverfassungsgericht had used the distinction between "religious truth" (Glaubenswahrheit) and a cultural tradition "legitimated by the continuous effect of historical realities" (Fortwirken geschichtlicher Gegebenheiten) to declare that a specific Christian-based public school model used in Baden-Württemberg was constitutional (BVerfG 4 I, 29, Abs. 104). The second of these decisions, the so-called cruxific decision in 1995, actually intervened to restrict the use of Christian symbols in public schools. On the grounds of state neutrality, the federal Supreme Court overruled Bavarian school legislation demanding that every elementary school classroom have a crucifix. However, the court specified that it was banning the crucifix as a symbol of a "specific religious conviction" (bestimmten religiösen Überzeugung) while again acknowledging that it is constitutional to affirm Christianity as "a formative factor of culture and education as it has developed in occidental history." ${ }^{25}$ This specification effectively served to undo the intended result of the court's ruling: Bavaria still legally prescribes a crucifix in every classroom. A revised version of the law in question was accepted as constitutional based on a clause stating that the crucifix expresses the will to realize the goals of the constitution "on the basis of Christian and occidental values."26

A decade later, these legal distinctions have been re-articulated to support the explicitly asymmetrical headscarf bans discussed, geographically far beyond the traditionally conservative southern German states of Bavaria and Baden-Württemberg. As I want to suggest here, the Schmittian model of the sovereign management of exceptions through which Asad theorizes the laicist French ban is not sufficient to adequately conceptualize the ways in which Christian heritage is thus (performatively) woven into the constantly evolving body of German legal discourse. ${ }^{27}$ To be sure, an Agamben-inflected, deconstructivist reading of Schmitt might go some way towards capturing the central and foundational status, which the quoted legal rhetoric ascribes to Christianity. For Agamben, it is precisely the exception, which creates the 
space of the juridico-political order, in the very process of suspending the rule of law (see I819). Nonetheless, the notion of exception simultaneously upholds the opposition thus questioned. In the German legislation discussed here, Christianity does not function as a moment of otherness haunting the space of secular modernity, but explicitly as the basis on which the latter is developed, in a mode of presumed continuity.

A closer theoretical match is provided, for example, by Jean-Luc Nancy's narrative of how the theological-political relation developed in European history, a narrative according to which it was the "event" of Christianity that first created the distinction between church and state "eventually produced" by modern democracy (107). For Nancy, this separation creates the political (as autonomy), but it cannot ever undo the complementary force of heteronomy. Even in the French revolution's laicist model, the "afterthought" of "fraternity" resists the totalization of political autonomy as "the residual minimum of political affect" (108). For Nancy, “[d]emocracy is thus by birth (...) too Christian, and not Christian enough" (I I0). In his analysis, the modern project of radicalizing political autonomy is fundamentally instable because it is necessarily haunted by heteronomy, specified as the very "desire to celebrate community" that it represses (109).

In more forceful rhetoric, similar tensions are postulated by Slavoj _i_ek. For him, a "fundamental impasse of democracy" is created by the circumstance that "the abstraction proper to democracy can never dissolve the 'substantial ties' —of ethnicity, nation, etc." (add, for our context, religion) "- that it negates” (Looking Awry, 162, 164). As I have discussed elsewhere in detail, Zizek develops "this constitutive paradox" at the heart of democracy (I68) out of his reading of Lacanian psychoanalysis, which emphasizes the intervention of the "Real" in the performative constitution of identity, or more specifically authority (on this point see already Butler, Bodies). In The Sublime Object of Authority, Zizek develops his particular take on performativity theory by conceptualizing the functioning of ideology through Pascal's early modern discussion of the law's "mystical” foundation. The latter, of course, has also been famously re-articulated by Derrida, who translates "mystical” as "radically contingent," thereby asserting that the authority of the law is founded on an act of performative violence. Whereas Derrida adopts a primarily deconstructive perspective, Zizek is more interested in the effective functioning of ideology and, in fact, asserts its necessity. Contingency is evacuated as the Real intervenes to provide the performative process of signification with continuity: as "a hard 
kernel resisting symbolization" (Sublime Object, 16I), it "remains the same in all possible worlds" (169). Even while the performatively established law is "constitutively senseless" (37), it cannot simply be changed in Zizek's world. As he claims elsewhere with respect to Judith Butler's account of performative subversion, "the gargantuan symbolic matrix is far too deep-rooted and 'substantial' to be effectively undermined by the marginal gestures of performative displacement" (Sehr innig, 34).

In Grimassen des Realen, Zizek develops this argument as a critique of the French Revolution, which basically had to fail, and could only result in terror, because the king's sublime body is not open to resignification. Connecting this argument to the discussion of democracy and the "substantial" ties it fails to undo, Zizek's theory can be summarized as suggesting that the revolutionary assertion of laicity as the character of the modern French Republic was shot through with impossibility because there "is" no "sovereign" play of/with power signifiers in Asad's Schmittian sense; instead, the "real” remainders of tradition stubbornly re-asserted their anti-democratic presence in the democratic field. I would caution that this narrative underestimates the performative force (and effective positing) of laicity in the French context-an objection which underlines my suspicion that Zizek's model does not describe a universal logic of identity. The contemporary majority-German articulation of Christian tradition within the political order, however, may in fact resonate more closely with this model than with that of a sovereign managing "exceptions" to the principle of laicity. In the ideological process of the cited headscarf legislations, Christian religion is called upon as that remainder of the "Real" of tradition which, for Zizek, constitutes (also presumably secular, democratic) identity in the first place (Grimassen 97).

Importantly, my own quotation marks around "Real" signal that in associating Zizek's Lacanian model with this German context, I am not subscribing to its epistemological premises. With Butler, I generally assert the possibility of political change based on the exchange and resignification of the signs of power. This does not, however, necessarily imply subscribing to a notion of sovereign free play. In her reading of Derrida in Excitable Speech, Butler cautions that the play of signifiers is restrained by context; the accumulated weight of repeated hegemonic (or "traditional") uses inheres "in certain speech acts in ways that are very difficult to shake" (I6I). What Zizek succinctly describes is, then, an ideological process which may prove to 
function with considerable stability, but still can be challenged in principle. The figures of foundation and necessity function as crucial rhetorical devices shaping this ideological process.

In the German headscarf legislations, these figures have not remained unchallenged. For example, the majority opinion in the 2003 Supreme Court decision does acknowledge the significance of (Christian) tradition as well, but it does so in a language which is reminiscent of Asad's Schmittian sovereign rather than a state "subject" haunted by the Real. Thus, the court suggested that new legislation could be different in individual German states because in negotiating the contrary claims of everybody's positive and negative freedoms to and from religion, it was "permissible also to take into account school traditions, the denominational constitution of the population and the degree of their religious rootedness." 28 The preceding crucifix decision, however, which was employed as legal precedent in the openly asymmetrical headscarf bans responding to the Supreme Court decision, uses a language of necessity in specifying the role of Christian tradition in the state:

Even a state which has committed itself ... to religious-ideological neutrality cannot shed the culturally transmitted and historically rooted values and attitudes on which social cohesion is based and on which the execution of its tasks depends. The Christian faith and the Christian churches have been of paramount importance in that regard, irrespective of how one may judge their legacy today. The state cannot be indifferent to the traditions of thought, experiences of meaning and behavioural patterns they have produced. ${ }^{29}$

If we take this rhetoric of foundational necessity at face value, what happens to the differential construction which distinguishes "democratic" Christian culture from Islamic "political theology"? In line with the discursive foreclosure of modern Muslim identities discussed above, Ludin's self-positioning as a democratic citizen choosing to wear a headscarf (see Weber 45) was insistently contested in the media through abounding charges of her affiliations with Islamist groups. ${ }^{30}$ But what exactly is the status of (even individual) choice in "enlightened" majorityGerman Christian culture where Christianity's foundational significance for collective identity is rhetorically endowed with an unquestionable staying power reminiscent of Zizek's Lacanian Real? In which ways is that form of political theology (not) compatible with (more or less secular) democracy? 
In a self-reflexive comment following his propositions on the instability of democratic secularism, Nancy wonders whether he will be understood to describe "a kind of vague fascism" (109). Returning to the analytical plane, he then asserts that "fascisms, and with them 'real' communisms ... have well and truly seized upon an unutilized desire to celebrate community" (109). Incidentally, the call for German anti-headscarf legislation was initially made by neo-fascists. When Ludin's case first became public in Baden-Württemberg, the right-wing Republikaner, who had seats in the state parliament at the time, initiated a debate on the basis of the state constitution's above-quoted references to Christianity (see Weber 43). Clearly, their "seizing upon" the very Christian rhetoric which was eventually going to underwrite the new headscarf legislation does not make this rhetoric itself, or the law it supported, fascist per se. However, the embarrassing confluence of "extremist" and majority strategy highlights the theoretical —and political — trouble marked by Nancy's self-reflexive comment.

Having posited the force of heteronomy, or "desire for community," as a (transcendental) given, he proceeds to grant a certain truth to the fascist position, which can then be countered only by asserting community under a different name-in Nancy's case that of Christianity as associated with the primary quality of "love" (109). Of course, the deep implication of Christianity - including, as we have seen for example with Kelek, its rhetoric of love-in precisely the practices of discrimination at stake here underlines the precarious nature of such differentiations. Ernesto Laclau reminds us that any naming (or, for that matter, even identification) of "God," or "the fullness of the community," always implies exclusionary practices (146). While that critique should not prevent us from making distinctions between different, more or less democratic uses of Christianity, it highlights the need for investigations into "the very constitution of the "beyond"' (Laclau 145) in ongoing socio-symbolic practices, that is, the discursive configuration of community and religious tradition, the claims as to why it is necessary and in which form, etc. On a relatively pragmatic level, the legal as well as sociosymbolic constitution of contemporary society can be conceptualized differently even without declaring its complete "independence" from all traditions (and consequently only formal legitimation; see Habermas), simply by accounting for the rhetorical, processual, plural and heterogeneous character of traditions. While hegemonic discourse continuously reinscribes "the Christian-occidental" character of German culture, it can be rewritten to explicitly 
acknowledge the ways in which, from the Middle Ages to contemporary globalized society, this culture has been shaped by the interplay of constantly changing Christian, Jewish, Muslim and other religious traditions, as well as atheist discourses of collective identity.

\section{In Place of a Conclusion: Phobic "Games" of Signification, or: Berets and Other Hats}

As long as majority-German discourses block such rewritings, however, it looks like "Islamophobia" may continue to rule the public sphere. One of the stranger twists in the German headscarf debate came with the banning of a beret (Baskenmütze) by the Arbeitsgericht Düsseldorf in the summer of 2007. In response to the outlawing of her headscarf through the respective Northrhine-Westphalian legislation, a teacher had begun to cover her hair with this symbol of a regional/resistant national West-European identity, which found its way to the capital in the French Revolution and has since become associated with artists and intellectuals. ${ }^{31}$ The court argued that as worn by the teacher (in a way that completely covers her hair), the beret "can create the impression that it is a religious demonstration, comparable to the Islamic headscarf.",32

Arguments about "reader horizons" have played a central role throughout the German headscarf debates. The 2003 Supreme Court majority opinion acknowledged the widespread association of the headscarf with Islamic fundamentalism, but also Ludin's stated contrary intention as well as research on its significance as a symbol of identity in the diaspora. Since "all possible interpretations" (alle ... in Betracht kommenden Deutungsmöglichkeiten) had to be taken into account (Abs. 50), the court concluded that the headscarf could not be reduced to a symbol of women's oppression. Precisely the topos of accounting for all possible interpretations, however, has been prominently used also in the asymmetrical headscarf bans and their defense. As quoted above, the different laws variously outlaw outward behavior which "can create the impression" (Baden-Württemberg) or be understood "also as expressing" (Bavaria; my emphasis in both cases); and the Administrative Court in Leipzig supports the Baden-Württemberg law by arguing that the possibility that students or parents would read the headscarf as a symbol of political Islamism or women's oppression in fact provided sufficient ground for outlawing it (BVerwG 2 C 45.03, Abs. 22-23; see also the minority opinion in the Supreme Court decision, Abs. 122). 
On the one hand, this rhetoric of possibility_or potentiality, if not contingency-refers us back to Asad's logic of sovereignty. Choosing the headscarf's (relevant) significance, the Republic "plays" its "game" with religious meanings (504). On the other hand, her choices are certainly not completely "arbitrary" (thus Asad 502). In referring to the (imagined) takes of German readers, the asymmetrical German headscarf legislations quite explicitly ground their legitimacy in established (stereotypical) associations. The resulting spread and targeting of incriminated signs follows the operative logic of Freudian phobia, as characterized by associative displacements, which generate "mental barriers in the nature of precautions, inhibitions, or prohibitions" (Freud I 17). From the perspective of those affected by the (social) illness (of discrimination), the "wild" play of signs cannot be controlled. Or at least, its uncontrollable force is quite effective as a rhetorical topos: as claimed by the judge, the impression that the teacher's beret functions as a religious symbol "cannot be resisted." 33

Importantly, there are fissures in the discourses of anti-Islamism and (Christian) political theology in contemporary Germany, which point to spaces for intervention. While Ludin lost her case against the new law in Baden-Württemberg, another teacher successfully challenged the banning of her headscarf at Stuttgart's Administrative Court in 2006 by pointing out that in a public school in Baden-Baden, catholic sisters are teaching regular subjects - that is, not only religion-in their religious habit (Verwaltungsgericht Stuttgart). The argument turns the tables on the very distinction between culture and religion that justifies the asymmetrical bans. For in unfolding this distinction, the Administrative Court in Leipzig had explicitly stated that such forms of "religiously motivated clothing" were not covered by the wording of the law (Abs 34). In response to this challenge, the Stuttgart court ruled that the given asymmetry in fact violates the constitutional norm of equal treatment for all religions. "Nuns are saving Islam," the German weekly Der Spiegel titled (Hipp).

Of course, this is not yet the end of the story. While the Stuttgart court had even declared that the regional government could not appeal its decision, such an appeal was allowed by the Mannheim Administrative Court in March 2007, and in March 2008, the same court once more outlawed the teacher's headscarf. In response, her lawyer announced that they are now considering another appeal to the Bundesverfassungsgericht (Fleischmann). In Bavaria, the issue of the Christian nuns was brought up as well, but here, the state constitutional court underwrote 
the government's argumentation according to which their religious habit was covered by the acceptable privileging of Christian tradition (“Kopftuch nein, Kutte ja”). Interestingly, the same local government explicitly allowed Muslim teachers to wear a "hat" (Hut) in place of their headscarf, since the former could not be mis/understood as anti-constitutional (ibid.). All of this happened before the beret-incident in Northrhine-Westphalia. Thus, a further spread of phobic prohibitions may yet put an end to the relative freedom of Bavaria's Muslim teachers. At the same time, the story indicates that the play of signs can exceed their regulatory arrestments.

\section{Works Cited}

Adelson, Leslie A. The Turkish Turn in Contemporary German Literature: Toward a New Critical Grammar of Migration. New York: Palgrave Macmillan, 2005.

Agamben, Giorgio. Homo Sacer: Sovereign Power and Bare Life. Trans. Daniel Heller-Roazen. Stanford, CA: Stanford UP, 1998.

Amir-Moazami, Schirin. Politisierte Religion. Der Kopftuchstreit in Deutschland und Frankreich. Bielefeld: transcript, 2007.

Arbeitsgericht Düsseldorf. 12 Ca 175/05, 29 June 2007. 123recht.net (http://www. I23recht.net/printarticle.asp?a=24009; accessed 08/I 2/2007).

Asad, Talal. "Trying to Understand French Secularism." Political Theologies: Public Religions in a Post-Secular World. Eds. Hent de Vries and Lawrence E. Sullivan. New York: Fordham UP, 2006. 494-526.

Baden-Württemberg. “Gesetz zur Änderung des Schulgesetzes vom 01.04.2004.” Universität Trier: Kopftuchverbot für Lehrkräfte in Deutschland (http://www.unitrier.de/index.php?id=7524\#c8466. 92; accessed 12/22/2007).

Bayern. "Bayerisches Gesetz über das Erziehungs- und Unterrichtswesen (BayEUG) in der Fassung der Bekanntmachung vom 3 I. Mai 2000.” (http://by.juris.de/by/EUG_BY_2000_rahmen.htm; accessed I2/23/2007).

Bayern. "Gesetz zur Änderung des Bayerischen Gesetzes über das Erziehungs- und Unterrichtswesen. Vom 23. November 2004 (GVBI. S. 443, Nr. 2I).” Universität Trier: Kopftuchverbot für Lehrkräfte in Deutschland (http://www.unitrier.de/index.php?id=7524\#c8466. 92; accessed 12/22/2007). 
Berlin. "Gesetz zur Schaffung eines Gesetzes zu Artikel 29 der Verfassung von Berlin und zur Änderung des Kindertagesbetreuungsgesetzes. Vom 27. Januar 2005.” Universität Trier: Kopftuchverbot für Lehrkräfte in Deutschland (http://www.unitrier.de/index.php?id=7524\#c8466. 92; accessed 12/22/2007).

Braun, Christina v., and Bettina Mathes. Verschleierte Wirklichkeit. Die Frau, der Islam und der Westen. Berlin: Aufbau, 2007.

Breger, Claudia. "The Leader's Two Bodies. Slavoj _i_ek's Postmodern Political Theology." Diacritics 3I.I (2001): 73-90.

Bremen. "Gesetz zur Änderung des Bremischen Schulgesetzes und des Bremischen Schulverwaltungsgesetzes. Vom 28. Juni 2005 (Brem. GBI S. 245, Nr. 31).” Universität Trier: Kopftuchverbot für Lehrkräfte in Deutschland (http://www.unitrier.de/index.php?id=7524\#c8466. 92; accessed 12/22/2007).

Broder, Henryk M. Hurra, wir kapitulieren! Von der Lust am Einknicken. Berlin: Verlag Wolf Jobst Siedler jr., 2006.

Brown, Wendy. "Subjects of Tolerance: Why We Are Civilized and They Are the Barbarians." Political Theologies: Public Religions in a Post-Secular World. Eds. Hent de Vries and Lawrence E. Sullivan. New York: Fordham UP, 2006. 298-317.

BVerfG (Bundesverfassungsgericht) 2 BvR 1436/02, June 3, 2003

(http://www.bverfg.de/entscheidungen/rs20030924_2bvr I43602.htm; accessed 2/12/2007).

-----. 4I, 29, December 17, 1975; "Simultanschule"

(http://www.servat.unibe.ch/dfr/bv04l029.html; accessed I2/23/2007).

----. 93, I, May 16, 1995; "Kruzifix"

(http://sorminiserv.unibe.ch:8080/tools/ainfo.exe?Command=ShowPrintVersion\&Name= bv09300I; accessed I2/23/07).

BVerwG (Bundesverwaltungsgericht Leipzig). 2 C 21.01, July 4, 2002

(http://www.bundesverwaltungsgericht.de/media/archive/2282.pdf; accessed 12/22/2007).

----. 2 C 45.03, June 24, 2004

(http://www.bundesverwaltungsgericht.de/media/archive/2282.pdf; accessed I2/23/2007). 
Butler, Judith. Bodies That Matter: On the Discursive Limits of Sex. New York, NY: Routledge, 1993.

---- . Excitable Speech: A Politics of the Performative. New York: Routledge, 1997.

Cesari, Jocelyne, Seán McLoughlin and the Network on Comparative Research on Islam and Muslims in Europe, eds. European Muslims and the Secular State. Burlington, VT: Ashgate, 2005.

Derrida, Jacques. “Force of Law: The 'Mystical’ Foundation of Authority.” Transl. Mary Quaintance. Deconstruction and the Possibility of Justice. Eds. Drucilla Cornell, Michael Rosenfeld and David Gray Carlson. New York (NY): Routledge, 1992. 3-67.

Eagleton, Terry. After Theory. New York: Basic Books, 2003.

El Tayeb, Fatima. “Dangerous Liaisons: Race, Nation and German Identity.” Not So Plain as Black and White. Afro-German Culture and History, 1890-2000. Eds. Patricia Mazón and Reinhild Steingröver. Rochester, NY: University of Rochester Press, 2005. 27-60.

Feddersen, Jan. “Wer ist hier -phob?” die tageszeitung 27 September 2007 (http://www.taz.de/index.php?id=alltag-artikel\&art=5259\&no_cache=I \&src=SE; accessed 10/13/2007).

Felgentreu, Fritz. [Rede zum Neutralitätsgesetz, January 20, 2005]. SPD-Fraktion im Abgeordnetenhaus (http://www.spdfraktionberlin.de/publikationenundreden/reden/rede felgentreu_neutralitaet; accessed 12/22/2007).

Fetzer, Joel S., and J. Christopher Soper. Muslims and the State in Britain, France, and Germany. Cambridge: Cambridge UP, 2005.

Fleischmann, Tobias. “Kopftuch ab—Gericht billigt Stuttgarter Schulgesetz.” Der Tagesspiegel 19 March 2008 (http://www.tagesspiegel.de/politik/deutschland/Kopftuchstreit;art I22,2497276; accessed 05/06/08).

Freud, Sigmund. "Analysis of Phobia in a Five-Year-Old Boy.” The Standard Edition of the Complete Psychological Works, Vol. X. London: Hogarth Press, 1955.

Habermas, Jürgen. “On the Relations Between the Secular Liberal State and Religion.” Political Theologies: Public Religions in a Post-Secular World. Eds. Hent de Vries and Lawrence E. Sullivan. New York: Fordham University Press, 2006. 25I-260. 
Henkel, Frank. [Presseerklärung des innenpolitischen Sprechers, 5 October 2004] CDU-Fraktion Berlin (http://www.cdu-fraktion.berlin.de/aktuelles/presseerklaerungen/ kreuz_und_kippa_gehoeren_zur_christlich_abendlaendischen_kultur; accessed 12/22/07).

Hessen. “Gesetz zur Sicherung der staatlichen Neutralität. Vom I8. Oktober 2004.” Universität Trier: Kopftuchverbot für Lehrkräfte in Deutschland (http://www.unitrier.de/index.php?id=7524\#c8466. 92; accessed 12/22/2007).

Hipp, Dietmar. “Nonnen retten den Islam.” Spiegel online 8 July 2006 (http://www.spiegel.de/schulspiegel/0,I5 |8,425678,00.html; accessed I2/24/2007).

Joppke, Christian. "State Neutrality and Islamic Headscarf Laws in France and Germany." Theory and Society 36 (2007): 31 3-342.

Kelek, Necla. Die fremde Braut. Ein Bericht aus dem Inneren des türkischen Lebens in Deutschland. Köln: Kiepenheuer \& Witsch, 2005.

------. Die verlorenen Söhne. Plädoyer für die Befreiung des türkisch-muslimischen Mannes. Köln: Kiepenheuer \& Witsch, 2006.

Klausen, Jytte. The Islamic Challenge: Politics and Religion in Western Europe. Oxford: Oxford UP, 2005.

Kleff, Sanem. "Die unvollendete Säkularisierung und der Islam in Deutschland.” Politik ums Kopftuch. Eds. Frigga Haug and Katrin Reimer. Hamburg: Argument, 2005. 85-94.

“Kopftuch nein, Kutte ja: Verfassungsurteil in Bayern.” Spiegel online I5 January 2007 (http://www.spiegel.de/schulspiegel/), I5 I8,druck-459736,00.html; accessed I2/2/2007).

Laclau, Ernesto. “On the Names of God.” Political Theologies: Public Religions in a Post-Secular World. Eds. Hent de Vries and Lawrence E. Sullivan. New York: Fordham University Press, 2006. I37-I47.

Lau, Mariam. “Bigotte Debatte.” Die Welt 30 September 2006 (http://www.welt.de/data/2006/09/30/1055075.html?prx=I; accessed 10/10/2006).

Nancy, Jean-Luc. “Church, State, Resistance.” Political Theologies: Public Religions in a Post-Secular World. Eds. Hent de Vries and Lawrence E. Sullivan. New York: Fordham University Press, 2006. I-2-II2. 
Niedersachsen. "Niedersächsisches Schulgesetz."

(http://www.schure.de/nschg/nschg/nschgl.htm; accessed I2/22/07).

"Offener Brief: Zur antisemitischen Gewalt in Kreuzberg-Friedrichshain." HaGalil.com

07.09.2004 (http://www.hagalil.com/archiv/2004/09/kreuzberg.htm; accessed |2/2|/2007).

Ozyurek, Esra. "Converted German Muslims and Prospects for a German Islam." Paper given at German Studies Association, October 2007, San Diego.

PAB. “Auch Baskenmütze ist ein Kopftuch.” Die tageszeitung II April 2008: 7.

Puar, Jasbir K. “Queer Times, Queer Assemblages.” Social Text 84-85 (23.3-4; 2005): I2I-139.

Rasch, William. "Messias oder Katechon? Carl Schmitts Stellung zur politischen Theologie.” Politische Theologie: Formen und Funktionen im 20. Jahrhundert. Eds. Jürgen Brokoff and Jürgen Fohrmann. Paderborn: Schöningh, 2003. 39-54.

Rath, Christian. “Urteil in Hessen: Roland Kochs Kopftuchverbot bleibt.” Die tageszeitung II

December 2007 (http://www.taz.de/l/leben/alltag/artikel///roland-kochs-

kopftuchverbot-bleibt/?src=HL\&cHash=04794aa3d0; accessed 12/23/2007).

Rødstøl, Kristine. "Headscarves, Religion, and the State: The Reality of European Commitment to Human Rights for All" (I7 March 2004) (http://www.forum 18.org/Archive.php?query=Headscarves\&religion=all\&country=all\&res ults=10; accessed 12/23/2007).

Saarland. "Gesetz Nr. 1555 zur Änderung des Gesetzes zur Ordnung des Schulwesens im Saarland (Schulordnungsgesetz) vom 23.06.2004.” Universität Trier: Kopftuchverbot für Lehrkräfte in Deutschland (http://www.uni-trier.de/index.php?id=7524\#c8466. 92; accessed 12/22/2007).

Schmithals, Walter. "Islam heißt Staatsreligion." Die Zeit 9 February 2006 (http://zeus.zeit.de/text/2006/07/Muslime; accessed 2/27/2006).

Schneider, Peter. "The New Berlin Wall.” The New York Times Magazine December 4, 2005: 6671.

Schulz, Stefan. "Staatsdienst ohne Kopftuch und Kippa. Parlament beschließt Neutralitätsgesetz für öffentlichen Dienst." Berliner Morgenpost 2I January 2005 (http://www.morgenpost.de/content/2005/0I/2I/berlin729947.html; accessed October 15, 2007). 
Seidel, Eberhard. "Gesundes Volksempfinden 2006." die tageszeitung 7 October 2006: 12. _en, Faruk. "The Historical Situation of Turkish Migrants in Germany." Immigrants \& Minorities 22 (2003): 208-227.

Siemes, Christof. “Wir gegen die.” Die Zeit 23 February 2006 (http://www.zeit.de/2006/09/Zeit_d_Wlfe?page=all; accessed 03/21/06).

Spivak, Gayatri: "Can the Subaltern Speak? Speculations on Widow Sacrifice." Wedge 7-8 (1985): 120-130.

Terkessidis, Mark, and Yasemin Karakasoglu. "Gerechtigkeit für die Muslime! [Petition von 60 Migrationsforschern.]" Die Zeit I February 2006 (http://www.zeit.de/2006/06/Petition; accessed 12/24/2007).

Verfassung des Landes Baden-Württemberg vom II. November 1953 (GBI. S. I73; http://www.lpb-bw.de/bwverf/bwverf.htm; accessed I2/22/2007).

Verwaltungsgericht Stuttgart: "Kopftuchstreit. Az.: 18 K 3562/05 - Pressemitteilung vom 07.07.2006" (http://www.justizportalbw.de/servlet/PB/menu//200794/index.html?ROOT=I| 92939; accessed 12/24/2007).

Vries, Hent de. "Introduction." Political Theologies: Public Religions in a Post-Secular World. Eds. Hent de Vries and Lawrence E. Sullivan. New York: Fordham University Press, 2006. I88.

Vries, Hent de, and Lawrence E. Sullivan: "Preface." Political Theologies: Public Religions in a PostSecular World. Eds. Hent de Vries and Lawrence E. Sullivan. New York: Fordham University Press, 2006. ix-xii.

Weber, Beverly. "Cloth on her Head, Constitution in Hand: Germany's Headscarf Debates and the Cultural Politics of Difference." German Politics and Society 22.3 (2004): 33-64.

WDR. "Baskenmütze geht auch nicht." wdr.de 29 June 2007 (http://www.wdr.de/themen/politik/nrw02/integration/kopftuch/070629.jhtml; accessed 12/24/2007).

Williams, Rowan. "Introducing the Debate: Theology and the Political." Theology and the Political: The New Debate. Eds. Creston Davis, John Milbank and Slavoj_i_ek. Durham: Duke UP, 2005. I-3. 
Yildiz, Yasemin. “Agency, Address, Occidentalism: The Discourse of 'Muslim' Women in Europe.” Keynote Lecture. De/Konstruktionen von Orientalismus. Eine geschlechterkritische Intervention in die Herstellung des Eigenen am Anderen. 21 .-23.6.2007, Humboldt University, Berlin.

_i_ek, Slavoj. Grimassen des Realen. Jacques Lacan oder die Monstrosität des Aktes. Transl. Isolde Charim and others; ed. Michael Wetzel. Köln: Kiepenheuer \& Witsch, 1993.

_i_ek, Slavoj. Looking Awry. An Introduction to Jacques Lacan through Popular Culture. Cambridge, Mass.: MIT, 1992.

_i_ek, Slavoj. Sehr innig und nicht zu rasch: zwei Essays über sexuelle Differenz als philosophische Kategorie. Transl. Erik M. Vogt. Wien: Turia \& Kant, 1999. _i_ek, Slavoj. The Sublime Object of Ideology. London: Verso, 1989. “Zum Beispiel: Berlin.” Die tageszeitung 2 December 2003: 4.

' I would like to thank Michael E. Auer for his critical feedback on the first draft of this paper, as well as Jeffrey Librett and an anonymous reviewer.

${ }^{2}$ Siemes. This particular wording is noticeable for the context of the argument on religious turns to be developed here. More commonly, Huntington's notion of a "clash of cultures" is translated into German as "Kampf der Kulturen.” In my own perception at least, the composite Kulturkampf still denotes its (inner-Christian) genealogy in the fight between Bismarck and the Catholic church in late nineteenth-century Germany (see Klausen I3, footnote I).

${ }^{3}$ See particularly the work coming out of Wilhelm Heitmeyer's Institute for Interdisciplinary Research on Conflict and Violence. One of the figures provided on the webpage is that in 2006, 28.5\% of Germans agreed that Muslims should not be allowed to immigrate into Germany (http://www.uni-bielefeld.de/ikg/Feindseligkeit/lslamphobie.html; accessed 12/23/07). For an overview see also http://de.wikipedia.org/wiki/lslamfeindlichkeit (accessed I2/23/07). Polemically, a commentary in the left-wing daily die tageszeitung suggests that by now, "an entire people is united in anti-Islamic resistance" ("Ein ganzes Volk ist vereint im antiislamischen Widerstand.") The statistic data quoted here say that $91 \%$ of Germans associate the discrimination of women with the keyword "Islam," and that $40 \%$ are in favor of significantly ("stark") restricting the exercise of Islamic faith in Germany (Seidel).

${ }^{4}$ The work of Kelek, who is often compared to Ayaan Hirsi, was, for example, distinguished with the annual Geschwister Scholl-prize in 2005, which has generally been awarded for Holocaust-related works. Kelek was also invited to participate in the "Islam conference" initiated by the German government - an indication also of the government's heritage- rather than practice-based definition of religious belonging (Ozyurek). Kelek's populist work has been harshly criticized by a number of German migration scholars (see Terkessidis and Karakasoglu).

${ }^{5}$ Although Kelek does not develop the contemporary political subtext, her discussion of the respective "fundamental theological dissent" (I59) between Christianity and Islam invites associations of suicide bombing: unlike in the biblical story of Abraham, she insists, the son in the Koran equivalent knowingly and willingly sacrifices himself.

${ }^{6}$ See "Offener Brief: Zur antisemitischen Gewalt in Kreuzberg-Friedrichshain;" "Zum Beispiel Berlin.”

${ }^{7}$ Kelek's discussion of Islam in terms of ritual slaughter provides an indication of Judaism's uncertain in-between place in the debate. While she emphasizes the difference between the biblical Abraham story and its correlate in the Koran, her chapter title "Abraham's sons" posits a line of continuity between the "barbarism' of the "Old Testament" and its Muslim actualization, which feeds Christian self-definitions against Judaism (Die verlorenen Söhne, 159). 
${ }^{8}$ en's data show a correlation between the growth of observance in Turkish-German communities and the length of an immigrant's stay in Germany (224). This seems to suggest that in addition to larger transnational trends towards religion (both Islam and Christianity), immigrant experiences specifically inflect the observed increases in religious commitment.

${ }^{9}$ Ultimately, of course, relying on Orientalist conceptions of Eastern despotism, the contemporary re-articulation of this topos goes back at least to Huntington (see Klausen 4).

${ }^{10}$ This includes some work in German Kulturwissenschaft. Prominently, v. Braun's and Mathes' contribution to the headscarf debate criticizes majority German discourses on Islam by questioning the Christian/Western fascination with unveiling. Their discursive intervention is based on a critique of secular modernity: "Der Fundamentalismus breitet sich dort aus, wo das Fundament fehlt—und zwar das religiöse Fundament" (13). In holding on to a grand narrative of religious conflict, the book unfortunately re-inscribes most of the anti-Islamic stereotypes it critiques. "The German Beamtenstatus is that of a civil servant with a specific loyalty commitment in exchange for tenured status, pension privileges, etc. On the argumentation of the Oberschulamt Stuttgart (July 10, 1998) see the 2003 decision of the federal supreme court (BVerfG Abs. 5; on the Beamtenstatus ibid, Abs. 79 and 90-10I [dissenting opinion]).

12 “ “. . ohne dass dafür gegenwärtig die erforderliche, hinreichend bestimmte gesetzliche Grundlage besteht” (ibid). 13 "Der Gesetzgeber hat bei der Aufstellung von Eignungskriterien ... grundsätzlich eine weite Gestaltungsfreiheit" (Abs. 34).

14 "Der mit zunehmender religiöser Pluralität verbundene gesellschaftliche Wandel kann für den Gesetzgeber Anlass zu einer Neubestimmung des zulässigen Ausmaßes religiöser Bezüge in der Schule sein" (Leitsatz 2).

${ }^{15}$ See Fetzer and Soper 105-108. The issue of religious instruction in public schools has been tackled independently with various compromise solutions on the state level (for an overview of the state of affairs as of 2005 see ibid., III-II6).

${ }^{16}$ Similar in some respects, the respective legislation passed in Bremen bans "all demonstrative religious symbols" by teachers, judges, police officers, etc. ("das Tragen aller demonstrativen Religionssymbole in hoheitlicher Funktion;" Bremen). However, it also participates in some of the rhetoric used in the openly asymmetrical legislations in other German states.

17 "Nur Symbole, die—wie kleine Halskreuze—als Schmuckstücke getragen werden, sind davon ausgenommen" (Schulz); see also Felgentreu.

18 "Lehrkräfte an öffentlichen Schulen nach § 2 Abs. I dürfen in der Schule keine politischen, religiösen, weltanschaulichen oder ähnliche äußeren Bekundungen abgeben, die geeignet sind, die Neutralität des Landes gegenüber Schülern und Eltern oder den politischen, religiösen oder weltanschaulichen Schulfrieden zu gefährden oder zu stören. Insbesondere ist ein äußeres Verhalten unzulässig, welches bei Schülern oder Eltern den Eindruck hervorrufen kann, dass eine Lehrkraft gegen die Menschenwürde, die Gleichberechtigung der Menschen nach Artikel 3 des Grundgesetzes, die Freiheitsgrundrechte oder die freiheitlich-demokratische Grundordnung auftritt. Die Wahrnehmung des Erziehungsauftrags nach Artikel I 2 Abs. I, Artikel I 5 Abs. I und Artikel I 6 Abs. I der Verfassung des Landes Baden-Württemberg und die entsprechende Darstellung christlicher und abendländischer Bildungs- und Kulturwerte oder Traditionen widerspricht nicht dem Verhaltensgebot nach Satz I. [...]" (Baden-Württemberg).

19 "Die Jugend ist in Ehrfurcht vor Gott, im Geiste der christlichen Nächstenliebe [...] zu erziehen" (Verfassung).

20 "Beamte ... dürfen ... Kleidungsstücke, Symbole oder andere Merkmale nicht tragen oder verwenden, die objektiv geeignet sind, das Vertrauen in die Neutralität ihrer Amtsführung zu beeinträchtigen oder den politischen, religiösen oder weltanschaulichen Frieden zu gefährden. Bei der Entscheidung über das Vorliegen der Voraussetzungen nach Satz I und 2 ist der christlich und humanistisch geprägten abendländischen Tradition des Landes Hessen angemessen Rechnung zu tragen;" the addition to the school law is worded almost identically (Hessen).

21 "Das äußere Erscheinungsbild von Lehrkräften darf ... keine Zweifel an der Eignung der Lehrkraft begründen, den Bildungsauftrag der Schule (§ 2) überzeugend zu erfüllen." §2.I reads: "Die Schule soll im Anschluss an die vorschulische Erziehung die Persönlichkeit der Schülerinnen und Schüler auf der Grundlage des Christentums, des europäischen Humanismus und der Ideen der liberalen, demokratischen und sozialen Freiheitsbewegungen weiterentwickeln" (Niedersachsen).

22 ". . . auch als Ausdruck einer Haltung verstanden werden können, die mit den verfassungsrechtlichen Grundwerten und Bildungszielen der Verfassung einschließlich den christlich-abendländischen Bildungs- und Kulturwerten nicht vereinbar ist" (Bayern, “Gesetz zur Änderung”). 
23 “Die Schule unterrichtet ... die Schüler bei gebührender Rücksichtnahme auf die Empfindungen anders denkender Schüler auf der Grundlage christlicher Bildungs- und Kulturwerte" (Saarland).

24 “. . . eine von Glaubensinhalten losgelöste, aus der Tradition der christlich-abendländischen Kultur hervorgegangene Wertewelt, die erkennbar auch dem Grundgesetz zu Grunde liegt” (BVerwG 2 C 45.03, Abs. 37).

25 “. . . prägenden Kultur- und Bildungsfaktor ..., wie er sich in der abendländischen Geschichte herausgebildet hat" (BVerfG 93.I, Abs. 19).

26 “. . . die obersten Bildungsziele der Verfassung auf der Grundlage christlicher und abendländischer Werte unter Wahrung der Glaubensfreiheit zu verwirklichen” (Bayern, "Gesetz über das Erziehungs- und Unterrichtswesen,” Art. 7 Abs. 3 ).

${ }^{27}$ Interestingly in this context, Schmitt has been defended as a thinker who is actually not an advocate of political theology, despite his famous use of the notion. In William Rasch's (Luhmann-inflected) reading, Schmitt is less interested in the theological origins of politics he acknowledges than in the process of secularization himself, and the political is theological for him only insofar as he sacralizes the autonomy of the political vis-à-vis the religious (39).

28 “. . . auch Schultraditionen, die konfessionelle Zusammensetzung der Bevölkerung und ihre mehr oder weniger starke religiöse Verwurzelung berücksichtigt werden dürfen” (Abs. 47; my emphasis).

29 "Auch ein Staat, der sich ... zu religiös-weltanschaulicher Neutralität verpflichtet, kann die kulturell vermittelten und historisch verwurzelten Wertüberzeugungen und Einstellungen nicht abstreifen, auf denen der gesellschaftliche Zusammenhalt beruht und von denen auch die Erfüllung seiner eigenen Aufgaben abhängt. Der christliche Glaube und die christlichen Kirchen sind dabei, wie immer man ihr Erbe heute beurteilen mag, von überragender Prägekraft gewesen. Die darauf zurückgehenden Denktraditionen, Sinnerfahrungen und Verhaltensmuster können dem Staat nicht gleichgültig sein (Abs. 22; my emphasis).

30 The background for these charges is that, after having been denied placement in Baden-Württemberg, Ludin moved to Berlin to teach in a private Islamic school. The school has been described as affiliated with Milli Görüs, an exile organization connected to Turkish Welfare Party (see Klausen 31), which is blacklisted by the Verfassungsschutz.

${ }^{31}$ http://de.wikipedia.org/wiki/Baskenm\%C3\%BCtze (accessed I2/21/2007).

32 "Durch die tief in die Stirn gezogene, die Haare der Klägerin komplett verdeckende Baskenmütze kann bei Schülern, Schülerinnen und Eltern der Eindruck entstehen, dass es sich um eine religiöse Bekundung, vergleichbar dem islamischen Kopftuch handelt" (Arbeitsgericht). The decision was confirmed by the next instance, the Düsseldorf Landesarbeitsgericht, in April 2008 (PAB).

33 “Dieses Eindrucks kann man sich nicht erwehren” (wdr). 